\title{
Which conformation does the $A B C$ transporter P-glycoprotein adopt in the physiological membrane environment?
}

\author{
Thomas Stockner ${ }^{1}$, Yaprak Dönmez ${ }^{1}$, Zahida Parveen ${ }^{2}$, Peter Chiba ${ }^{2 *}$ \\ From 18th Scientific Symposium of the Austrian Pharmacological Society (APHAR). Joint meeting with the \\ Croatian, Serbian and Slovenian Pharmacological Societies. \\ Graz, Austria. 20-21 September 2012
}

\section{Background}

The human genome contains 48 members of the $\mathrm{ABC}$ protein family. We focus on the multidrug resistance transporter $\mathrm{P}$-glycoprotein ( $\mathrm{P}$-gp, ABCB1), which is expressed at the blood-brain-barrier, in intestine, kidney, liver and macrophages. The first structure of an ABC exporter was from Staphylococcus aureus and showed a twisted architecture. The same fold was observed in MsbA, mouse P-glycoprotein and the human mitochondrial $\mathrm{ABCB} 10$ transporter. Although $\mathrm{ABC}$ exporters have now been crystallized in several conformations, uncertainty remained with respect to the physiological conformation because they seem not to be fully compatible with all biochemical evidence.

\section{Methods}

We applied homology modeling and MD simulations to determine the equilibrium conformation of the membrane-inserted transporter to test the hypothesis whether the observed conformations might be a consequence of the crystallization procedure or conditions. We inserted the transporter model into a pre-equilibrated membrane and carried out equilibrium simulations.

\section{Results and conclusions}

In equilibrium we observe the wings to come close, which is in compliance with experimental observations. Water becomes expelled from the hydrophobic region and the open passage between the water-filled pore and

\footnotetext{
* Correspondence: peter.chiba@meduniwien.ac.at

${ }^{2}$ Institute of Medical Chemistry, Center for Pathobiochemistry and Genetics, Medical University of Vienna, Vienna, Austria

Full list of author information is available at the end of the article
}

the cell exterior closes. Our results indicate that the closed conformation is energetically more favourable.

\section{Acknowledgements}

The study was funded by the Austrian Science Fund (FWF, grant P23319-B11).

\section{Author details}

'Institute of Pharmacology, Center for Physiology and Pharmacology, Medical University of Vienna, 1090 Vienna, Austria. ${ }^{2}$ Institute of Medical Chemistry, Center for Pathobiochemistry and Genetics, Medical University of Vienna, Vienna, Austria.

Published: 17 September 2012

doi:10.1186/2050-6511-13-S1-A68

Cite this article as: Stockner et al.: Which conformation does the ABC transporter P-glycoprotein adopt in the physiological membrane environment? BMC Pharmacology and Toxicology 2012 13(Suppl 1):A68.

Submit your next manuscript to BioMed Central and take full advantage of:

- Convenient online submission

- Thorough peer review

- No space constraints or color figure charges

- Immediate publication on acceptance

- Inclusion in PubMed, CAS, Scopus and Google Scholar

- Research which is freely available for redistribution

Submit your manuscript at www.biomedcentral.com/submit
C Biomed Central
C Biomed Central

C 2012 Stockner et al; licensee BioMed Central Ltd. This is an Open Access article distributed under the terms of the Creative Commons Attribution License (http://creativecommons.org/licenses/by/2.0), which permits unrestricted use, distribution, and reproduction in any medium, provided the original work is properly cited. 